Cornwall a Celtic Nation

Author(s): Henry Jenner

Source: The Celtic Review, Vol. 1, No. 3 (Jan., 1905), pp. 234-246

Published by:

Stable URL: http://www.jstor.org/stable/30069809

Accessed: 24-12-2015 01:23 UTC

Your use of the JSTOR archive indicates your acceptance of the Terms \& Conditions of Use, available at http://www.jstor.org/page/ info/about/policies/terms.jsp

JSTOR is a not-for-profit service that helps scholars, researchers, and students discover, use, and build upon a wide range of content in a trusted digital archive. We use information technology and tools to increase productivity and facilitate new forms of scholarship. For more information about JSTOR, please contact support@jstor.org. 


\section{CORNWALL A CELTIC NATION ${ }^{1}$}

\section{Henry Jenner}

THE history of Cornwall proves it to have been a separate nation in the past-separate from England on the one side and from the rest of Celtia on the other, ever since the progress of the Saxon conquest separated the Britons into different nationalities. No doubt the Cornish on occasions joined with Cambria and Armorica under one leader against their common enemy. They did this under their own Arthur in the sixth century, and under Rhodri Molwynog of Gwynedd and Ivor map Alan of Brittany in the eighth century; but these were temporary military emperors, and Cornwall continued to be governed by its own kings, Constantine ap Cador, Conan, Gerrans, Teuder, Blederic, Duniert, Hoel, and the rest, until Athelstan in 935 drove the Cornish out of Devon and set the Tamar for their boundary. This is what the Saxons called 'conquering' Cornwall, but as a matter of fact they never did conquer it. From Athelstan's time the rulers of Cornwall seem to have been called Earls, and to have generally allied themselves with the Saxons against a new common enemy, the Danes; but the last native earl, Condor, made common cause with William of Normandy and his army of Bretons and Normans against the Saxons, who were holding out in Devon, and especially at Exeter, and was tricked out of his earldom for his pains. But Cornwall did not become a part of England. It became an appanage of the Norman dynasty, and no more a part of England than Ireland became a century, or Wales two centuries, later. The dukes of Normandy, who happened to be also kings of the English, for the turn of the Sows Meleges was over, appointed earls of Cornwall generally of their own near kin. The Conqueror appointed his brother, Robert of Mortain ; some time after came Reginald de Dunstanville, appointed by Stephen. Henry II. appointed his son John,

1 A Paper read before the Pan-Celtic Congress at Carnarvon. 
afterwards king, and he in turn appointed his son Henry, afterwards Henry III. Perhaps the most distinguished earl was Richard, brother of Henry IIr., who was elected King of the Romans, and, had he lived, would have been Emperor. Edward Ir. appointed that dreadful ' bounder,' Piers Gaveston, to be earl, but he came to a bad end, and again the earldom was merged in the Crown. Edward II. then gave it to his son, John of Eltham, who died young, and Edward III. erected it into a dukedom and bestowed it upon his eldest son, Edward the Black Prince, since which time it has been the inherited title of the eldest son of the reigning sovereign. Unlike other British territorial titles of nobility, the dukedom of Cornwall really means something, for even now it involves certain jurisdictions which elsewhere fall to the Crown-foreshore rights, escheats, and other things, and, what is perhaps of more importance to the holder, a very considerable income. It was thus put into the same position as Wales, which, like Cornwall but unlike Ireland, was not included in the style and title of the king himself, but in that of his eldest son. Even the English did not consider Cornwall to be a part of England, but a separate earldom or duchy attached to the English Crown. All through the middle ages the official expression in Anglia et Cornubia was as common as England and Wales is now. I have found it as late as 1484. Even now certain laws, especially those relating to mining, are peculiar to Cornwall, and we still have our Cornish acre and our Cornish bushel. As late as the seventeenth century the separate nationality is clearly recognised. Thus we find John Norden saying of the Cornish about 1620, 'And as they are among themselves litigious, so seem they yet to retayne a kind of concealed envy against the English, who they yet affect with a desire of revenge for their fathers' sakes, by whom their fathers received their repulse.'

During the Civil Wars (in Clarendon's History and elsewhere) one finds the 'Cornish host,' the 'Cornish troops,' the 'Cornish army' under that grand Cornish hero, Sir Beville Granville, spoken of as quite distinct from the English 
cavalier army; as distinct as the 'Highland host' of the greatest of all Royalists, James Graham of Montrose. And splendid service they did too!

\footnotetext{
'Aye, by Tre, Pol, and Pen ye may know Cornishmen,

'Mid the names and the nobles of Devon;

But if truth to the King be a signal, why then

Ye can find out the Granville in Heaven.'
}

And to them the noblest of kings addressed that beautiful Letter of Thanks which Cornishmen may still read with pride on the walls of their old churches. He calls them a ' county,' no doubt, but a county may be a separate nation as well as an empire ; besides, it is 'Our loyal County of Cornwall,' his in an especial way, not as a mere shire of England. Some shires of England were fairly loyal at times, but he could not differentiate between them and the disloyal parts of England, or at any rate he did not, and I am disposed to consider that the opinion of King Charles is better worth taking than that of most people. And they were worthy of his thanks. Except Raglan, also a Celtic stronghold, Pendennis Castle was the last fortress to surrender to the rebels, and Cornwall might have held out almost indefinitely, had not most of the flower of Cornish chivalry fallen around the Granville in Lansdowne fight. As a nation the Cornish were loyal to the sons of the Martyr King, as a nation they refused to give up their loyalty at England's bidding, and when, in 1715, James Paynter had proclaimed King James III. at St. Columb, a Cornish jury refused to find him guilty of treason, and his countrymen gave him a triumphant progress through the length of Cornwall from Launceston to Trelissick. Which was a bold thing to do about that time.

These are a few of the things which show that the separate nationality of Cornwall has been recognised. There can be no question that as Scotsmen, Irishmen, Welshmen, and Manxmen recognise, quite apart from governments and jurisdictions, and without any necessary wish to alter existing conditions, their separate nationality from Englishmen, so do the Cornish, only perhaps rather more so. Go to any part of 
the British Empire, and even outside it to the United States and to South America, and everywhere, especially where there is mining to be done, you will find Cornishmen. They do not merge themselves in the people of the land, often they do not even bother to take up the franchise of a colony, or to make themselves American citizens. They and their children after them do not call themselves Australians, New Zealanders, Canadians, or Americans, but Cornishmen. They form Cornish associations, they stand together 'shoulder to shoulder' like Highlanders, and 'One and All' they hope to make enough to retire from exile and end their days in peace in their own dear land, perhaps in their native villages, for they have the homing instinct as well as the clan instinct of the Celt. Yet they have done as good service in peace and in war to the British Empire as any nation of their size, especially, like their Breton brethren, as sailors; but if going to a colony meant never coming back to Cornwall, they would not go at all.

Not long ago I was talking to a Scottish minister of the name of Macgregor, who told me something that reminded me of the Cornish. He said that his clan until about a century ago had had a religion of their own. He could not tell me any details, for it was just out of reach. 'What sort of thing was it?' I asked. 'Were they Catholics or Protestants?' 'No,' he answered, 'they were neither Catholics nor Protestants. They were just Macgregors.' And we may say the same sort of thing of the Cornish. They are British subjects, no doubt, and loyal ones at that, but they are neither Englishmen, Welshmen, Irishmen, nor Scotsmen, they are just Cornishmen.

And if Cornwall is a nation, is it a Celtic nation?

If he is a Celt who speaks a Celtic language, then $\mathrm{Mr}$. Rudyard Kipling's Nova Scotian negro, who 'called himself Macdonald and swore in Gaelic,' was a Celt, while thousands of Irishmen, Highlanders, Welshmen, and Bretons who speak only English or French are not Celts. If you say that a Celt is a person of Celtic blood who belongs to a nation that has pre- 
served its Celtic language, then you must needs be intricately ethnological, and will exclude the Silurian or Iberian element in South Wales, the pre-Celtic element in parts of Ireland, and the Bigaudens of the Penmarch district of Brittany, and you must measure a man's skull and decide whether he is brachycephalic or dolichocephalic before he is admitted to the Celtic fraternity - and that way madness lies. If, however, you define a Celtic nation as one which, mainly composed of persons of Celtic blood and possessing Celtic characteristics, and having once had a separate national existence, has preserved a separate Celtic language and literature, I am not disinclined to agree; and I am prepared to show that Cornwall fulfils those conditions.

The Cornish are mainly of Celtic blood. They are probably of more unmixed Celtic descent as a whole than any of the other Celtic nations, except perhaps the Bretons of Leon. There is little or no Scandinavian element among them, as in the Isle of Man, the Highlands and Islands of Scotland, and parts of Ireland. There is little or nothing of the pre-Celtic element, as in parts of Wales, parts of Ireland, and in the Bigauden district in Brittany. The shape of the country made it impossible for the Saxons to surround it and to absorb the inhabitants, as they did elsewhere. Indeed, the Saxons never settled Cornwall at all to any extent. Certain great Norman houses-Arundels, St. Aubyns, Granvilles, Bevilles, and others-acquired estates there, but like the Normans in Ireland who, as Giraldus says, became ipsis Hibernis Hiberniores, these were absorbed by the Celts and became as Cornish as any of them. As for Celtic characteristics, who can deny them to the Cornish? The imaginative temperament, the poetic mind, the superstitions, if you like to call them so, the religious fervour, the generosity of heart, the kindly hospitality, the passionate nature, the absolute honesty, the thirst for knowledge, the clan spirit, the homing instinct, all these are there. Like the Macgregors whom I have mentioned, the Celt may be a Catholic or a Protestant in the outward form of his religion, but below and 
beyond the outward form he is just a Celt, and the Wesleyanism of Cornwall and its offshoots, when you get below the surface and the mere outward expression, is nearer akin by far to that most beautiful of religions, Breton Catholicism, than the former is to English Protestantism or the latter to English Catholicism. There is no questioning the fact that the Cornishman himself recognises too that he is a near relation of the Welsh and the Bretons.

I think I have shown satisfactorily that the Cornish are mainly of Celtic blood (which I do not think any one has ever seriously denied), and I have pointed out that their known and recognised characteristics are eminently Celtic. It remains to show that they possess, and that they have preserved a Celtic language and literature.

And now some definitions must come in, and we must ask what is meant by 'preserving a language' or by an ' extinct language,' which is a shorter way of saying a language which has not been preserved. There are more ways of preserving a language than by talking it. Who shall say that Latin, Hebrew, and Sanskrit are extinct languages, and yet no one of them has been for centuries any one's mothertongue? If our modern knowledge of those languages, however complete now, had been laboriously revived by archæologists, as Assyrian was revived, by the discovery of ancient documents and bi-lingual inscriptions, and there had been no continuity of knowledge, one might call them 'extinct' languages, but that is not the case, for these three have been continuously preserved, by the Latin Church, the Jews, and the Hindus respectively, ever since the time when they were the literary forms of a spoken language.

I admit that the preservation of Cornish has been far less in degree than that of Latin, Hebrew, and Sanskrit, but I doubt whether there ever was so very much of it to preserve. It was the least cultivated of the Celtic languages, except perhaps Manx, and has the least copious vocabulary; but one may fairly say that most of what there was of it has been preserved, and that it has been con- 
tinuously preserved, for there has never been a time when there were not some Cornishmen who knew some Cornish; and though others have helped them and have written learnedly about the language, the preservation has been mainly the work of the Cornish themselves.

Probably until the time of Elizabeth the language was spoken over the whole duchy from the Tamar to the Land's End. The Reformation dealt it a hard blow, when the Bible and Prayer-book were used in English and were not translated into Cornish, but the people remained largely Catholic well into the seventeenth century, so that troubled them less than it might have. In the seventeenth century it began to recede, and in the Civil War period it was spoken from Truro westward, but very little to the east of that town. In 1700 it was still general among the working-classes in the western hundreds of Penwith and Kerrier, but the young people spoke it less and less, and though there were people who habitually used it down to the last quarter of the eighteenth century and persons who could speak it, and had done so in their younger days survived till nearly the middle of the nineteenth century, it would seem to have ceased to be any one's mother-tongue before the nineteenth ceutury began. But the work of preservation began before 1700, and though most of those who worked at the subject were very illequipped philologists, they did succeed in preventing the language from being quite lost. Moreover, apart from the literary work of educated men, there has been a continuous tradition among the less educated of the people, by which words, numerals, and phrases, which once were in common use, have been handed down as parts of the old language without the aid of books, and this tradition continues to this day. I myself received some of it from old people in Newlyn and Mousehole in 1875, so did Mr. Lach Szyrma, who found these people for me, so did Dr. Jago, the author of the English-Cornish Dictionary. Once there was more of it. It is said, though I do not vouch for the truth of the story, that there were old people in the early nineteenth century 
who habitually recited the Lord's Prayer and Creed in Cornish at their private prayers as they had been taught to do as children. Be this as it may, there were people who could have done so, and one instance came under my observation. My own mother-in-law (the late Mrs. Rawlings of Hayle), when she was a child, that is to say somewhere before 1830, had learned these two things in Cornish, though of course not as part of her religious instruction. Unluckily she had quite forgotten them in later life. Mr. Norris records also that he had heard an old man recite the Creed in Cornish, probably somewhat later. Beside the definite tradition of a small amount of Cornish as a separate language may be set the existence of a considerable number of Cornish words that are still in use in the mouths of the Cornish working-classes. There are perhaps a hundred or more of them, mostly, as may be supposed, the names of things. Thus a cow-shed is a bowjy, a pig-sty is a crow, a mine is a bal or a wheal, heather is grig or griglans, broom (the plant) is bannal, an elder-tree is a skow, a newt is a pajerpaw (four feet), a frog is a quilkin, ants are murrians, a toad is a cronack, to swallow is to clunk, to break is to scat, a milkingpail is a lattis, a dug well is a peeth, while a natural well or spring is a venton, a fiddle is a crowd. These are only a few taken at random, and of mining terms a very large proportion are Cornish, and so are many fishing terms. The names of places in the west of Cornwall are almost wholly Cornish, generally intelligible late Cornish, and not only the generic prefixes tre, pen, chy, bos, zawn, porth, enys, carreg, and the rest, but also such differentiating epithets as wartha and wollas, for upper and lower, gwidn and dew, for white and black, mear and bean for great and little, are very generally understood. Indeed vean, little, is a common term of endearment, as bach is in Welsh-cheeld vean, little child, is very common. But all this survival, though it constitutes in my opinion a faint flicker of actual life, is as nothing compared to the literary work of preservation, which began, as I have said, somewhere about 1700 and has continued to this voL. I. 
day. It began with the copying and translating into English by John Keigwin of the old Cornish literature, the Trilogy of the Ordinalia, the Drama of the Creation, the Poem of the Passion, the collecting of proverbs, verses, epigrams, and phrases, the translating of chapters of the Bible and other things into Cornish, and the collecting of words into vocabularies, besides the composition of a few original pieces by the same John Keigwin, by William Gwavas, William Kerrow, Thomas Tonkin, John Boson, and others. In the middle of it all to them enter Edward Lhuyd, a Welsh genius and a skilled philologist and grammarian, as philologists went in those days. He put their information into shape for them, and the result was his Cornish Grammar, published in 1707. But he could have done nothing without his Cornish helpers, who taught him the language (and his proficiency did them credit), translated the literature for him, and put all their knowledge at his disposal. In point of fact he supplied the artistic finish to their unskilled work. Later on the same work was taken up by others. Dr. William Borlase published a very copious vocabulary in 1759 . William Pryce republished Lluyd's Grammar, with a vocabulary substantially by Gwavas and Tonkin, and a considerable quantity of minor pieces from the collections of Gwavas and Borlase in 1790. Polwhele, Whitaker, and Davies Gilbert continued the work well into the nineteenth century. They did not do it very well, but that is not the point-they did it. Polwhele and Whitaker published fragments, specimens, and a short vocabulary. Davies Gilbert printed the Drama of the Creation and the Poem of the Passion, and a number of scraps of one sort and another, the latest appearing in 1827. From that time until 1853 very little appeared except occasional articles in magazines, though even then there were several Cornishmen who had some knowledge of the language. Then foreigners began to intervene. Hitherto, with the important exception of Lhuyd, the whole work had been done by Cornishmen. But the intervention of the foreigners, and highly skilled foreigners too, was no misfortune. 
In 1853 appeared the first edition of Zeuss's Grammatica Celtica, which included the Cornish vocabulary of the twelfth century and a good deal more, chiefly Davies Gilbert's publications. In 1859 Edwin Norris published his excellent edition of the Ordinalia, three fifteenth century dramas, Origio Mundi, Passio Christi, and Resurrectio Domini, with an equally excellent and learned essay on the grammar and literature generally. Then Dr. Whitley Stokes published his new editions and translations of the later drama of the Creation in 1864, and the Poem of the Passion in 1862, and Robert Williams of Rhydycroesau his splendid Cornish Lexicon in 1865 , but it is not taking away from the credit of either of these to say that they could have done comparatively little without the work of those Cornishmen of whom I have already spoken, to whose efforts, faulty and unlearned as they may have been, the preservation of the language is due. In 1872 Dr. Whitley Stokes published the Drama of St. Meriasek, a new discovery which added a fair number of words and forms. Then the natives took up the subject again. In $1876 \mathrm{I}$ published the results of my inquiries into the Traditional Relics of Cornish, and in 1877 a fragment of a late fourteenth, or early fifteenth, century poem or play discovered by me on the back of a charter in the British Museum, and much about the same time I also wrote two general papers on the language. The late Mr. William Copeland Borlase, who had published a few scraps from his ancestor's collections as early as 1866, edited John Boson's account of the Cornish language (in Cornish and English) in 1878, and ten years later appeared Dr. Jago's English-Cornish Dictionary. Meanwhile the 'foreigners,' Dr. Whitley Stokes and Professor Loth, have been adding greatly to our knowledge at intervals in the Revue Celtique and elsewhere, and up to the present time I have had the last word in my Handbook of the Cornish Language which has just now appeared.

The position of Cornwall as regards its language and literature in 1700 was very like that of the Isle of Man now, and the results of the efforts to preserve them will probably 
be repeated in the latter case, making allowance of course for the great advantage that the Manx people have in an improved knowledge of how to do it. I should like to illustrate what I mean by a reference to that language. It was only the other day that I came upon a remarkable opinion in the most widely circulated Guide-book to the Isle. It is interesting as an evidence of the ordinary cheap tripper's view of the matter; but then one knows very well what sort of illiterate unobservant idiot the cheap tripper is. And this is what is good enough for the cheap tripper in the Isle of Man. "There is no occasion for the tourist to trouble himself about the Manx language. Early in the present century' (he means the last century, for the book is dated 1904, but he can't even get his chronology right) 'the then bishop spoke of it thus in a letter to his wife: "It is an unmitigated portion of the curse of Babel."' What the Bishop of Sodor and Man said is not evidence, but to one who considers the Manx language to be the most interesting thing in that most interesting island, this opinion sounds curious. Yet it is probably well suited to the readers of the book, which, after all, does tell you where the golf links are, so what more can any reasonable man expect? There were people, and Manxmen too, I fear, a century ago, who would have been glad to get rid of Manx as an obstruction. Now, as Cornishmen did two centuries ago, they are eagerly preserving every bit that is left of it. They will succeed in preserving it on paper ; they will prolong its life as a spoken language a little longer; they will preserve, and perhaps add to, its little literature, but that is all. When the present old people are dead, it will cease to be any one's mother-tongue. I do not want to throw cold water on the laudable efforts of the Manx Language Society. Let them aim high ; let them set before themselves the object of preserving it in saecula saeculorum, and they will probably preserve more of it for a longer time than if they made languid efforts. The Cornish, even those who loved their language most, saw that as a spoken tongue it was doomed, and it is possible that their efforts were marred 
by that knowledge. But though the Manx may preserve the whole of their speech as a literary language, and even as an artificially spoken language, they can seriously hope for no more.

The Cornish are again beginning to show their interest in their old language. I do not say that they are likely to introduce it as a spoken language to the exclusion of English, but I think a good many of those who do not know it will repair that defect, and will learn certainly to read it, probably to write, and possibly to speak it. That it can be spoken intelligibly by modern people was proved very clearly last year at the Breton Congress at Lesneven. At the dinner which ended the Congress I made a speech of about four or five minutes' duration in Cornish, and-much to my astonishment, for I must confess that I did not think it would be so-I was very well understood by my Breton audience. I spoke fair Cornish, and did not 'fake' it to suit Breton, and I pronounced it as I supposed a seventeenth century Cornishman would have pronounced it. Of course I spoke slowly and distinctly, and it is possible that, having been for the previous fortnight in the middle of Breton-speaking people, I had caught something of the Breton intonation unawares; also it was not very difficult to conjecture what I was likely to talk about; but making all due allowances for these things, it is a remarkable fact that a speech in Cornish was understood by an audience of Bretons, only one of whom had studied Cornish.

And I have good reason to know that the awakening of Cornwall has begun. Since, some six months ago, the Cornish Telegraph, a local paper of Penzance, began to make known my Cornish Grammar, I have received many letters from intending subscribers. They are of all classes of the community, no doubt, but certainly a very large proportion belong, not to the rich and leisured class, who might take up Cornish as a fashion, as they take up golf or motoring, but to the classes of hard-working clerks, small business men, shopkeepers, and artisans, the classes that form the backbone 
of Cornish Methodism-a very different sort of people from the same classes in a non-Celtic country-and I found that perhaps the most intelligent of these letters was from an ordinary walking postman. People of that class in Cornwall want to know things, and, what is more, they generally succeed.

\section{THE CELTIC ELEMENT IN LOWLAND SCOTLAND}

\section{James Ferguson}

I

Scotland has long been known as the country of two races, speaking different languages and with different manners and customs. The contrast struck the minds of foreign observers who visited the country before the Union of the Crowns, and language and local conditions combined to produce the broad division into Lowlanders assumed to be altogether Teutonic, and Highlanders classified as Celtic. In some respects there would seem, superficially, to be more in common between a Scot of the eastern seaboard and a Dutchman than between the former and a western Islesman. The obvious contrastmore marked one or two centuries ago, when the Lowlander had long been engrossed in peaceful pursuits while the Highlander dwelt apart behind the Grampians, retaining his martial traditions-favoured the popular notion that the Anglo-Saxons had bodily driven out the Celts from the lowland shires to a refuge in the recesses of the mountains. The theory is embodied in stirring lines by Sir Walter Scott:-

\footnotetext{
'Saxon, from yonder mountain high,

I marked thee send delighted eye,

Far to the south and east, where lay,

Extended in succession gay,

Deep waving fields and pastures green,

With gentle slopes and groves between :-

These fertile plains, that softened vale,

Were once the birthright of the Gael;

The stranger came with iron hand,

And from our fathers reft the land.'
} 